Summary of clinical details of four patients with $M$ chelonei infection

\begin{tabular}{|c|c|c|c|c|c|c|}
\hline Case No & $\begin{array}{l}\text { Sex and } \\
\text { age (years) }\end{array}$ & Initial symptoms & Treatment history & $\begin{array}{l}\text { Treatment } \\
\text { after admission }\end{array}$ & Complications & $\begin{array}{c}\text { Final } \\
\text { hand function }\end{array}$ \\
\hline 1 & F 72 & $\begin{array}{l}\text { Stiffness of both middle } \\
\text { fingers for one year }\end{array}$ & $\begin{array}{l}\text { Multiple steroid injections to } \\
\text { both fingers; streptomycin, } \\
\text { isoniazid, rifampicin, and } \\
\text { pyrazinamide after incisional } \\
\text { biopsy }\end{array}$ & $\begin{array}{l}\text { Ray amputation of right } \\
\text { middle finger, Hibitane bath, } \\
\text { secondary suture four weeks } \\
\text { later, kanamycin for four } \\
\text { months }\end{array}$ & $\begin{array}{l}\text { Recurrence of infection in left } \\
\text { middle finger four months } \\
\text { after chemotherapy with- } \\
\text { drawn, debridement and } \\
\text { chemotherapy given }\end{array}$ & $\begin{array}{l}\text { Right hand satisfactory, good } \\
\text { movement, power of grip fair, } \\
\text { left hand good }\end{array}$ \\
\hline 2 & F 73 & $\begin{array}{l}\text { Stiffness and triggering of } \\
\text { left middle finger }\end{array}$ & $\begin{array}{l}\text { Multiple steroid injections, } \\
\text { incision and drainage }\end{array}$ & $\begin{array}{l}\text { Ray amputation, amikacin for } \\
\text { five months, Hibitane bath }\end{array}$ & $\begin{array}{l}\text { Tinnitus, changed to doxycy- } \\
\text { cline and co-trimoxazole for } \\
\text { two months, delay of wound } \\
\text { healing for six months }\end{array}$ & $\begin{array}{l}\text { Fair, good movement, power } \\
\text { of grip weak }\end{array}$ \\
\hline 3 & F 56 & $\begin{array}{l}\text { Post-traumatic arthritis of } \\
\text { left wrist (Colles' fracture), } \\
\text { osteoarthritis of right knee }\end{array}$ & $\begin{array}{l}\text { Multiple steroid injections } \\
\text { to left wrist and right knee }\end{array}$ & $\begin{array}{l}\text { Kanamycin for six months, } \\
\text { synovectomy of right knee }\end{array}$ & $\begin{array}{l}\text { Infected granuloma in left } \\
\text { thenar eminence four weeks } \\
\text { after chemotherapy } \\
\text { withdrawn, treated with } \\
\text { complete excision }\end{array}$ & Good \\
\hline 4 & F 62 & $\begin{array}{l}\text { Stiffness in left middle and } \\
\text { little fingers for five months }\end{array}$ & $\begin{array}{l}\text { Multiple steroid injections to } \\
\text { both fingers }\end{array}$ & $\begin{array}{l}\text { Synovectomy of both fingers, } \\
\text { amikacin for three months }\end{array}$ & & $\begin{array}{l}\text { Good, mild triggering in } \\
\text { middle finger }\end{array}$ \\
\hline
\end{tabular}

drugs'; drugs that may be useful include erythromycin, ${ }^{4}$ doxycycline, kanamycin, and amikacin. The infection is probably inoculated by contaminated needles. Steroids may perpetuate the infection by suppressing local inflammatory response. As steroid injections are used widely in both hospital and general practice clinicans must be aware that underlying infections may be exacerbated: Disposable syringes should be used whenever possible.

In conclusion, I believe that early surgery (debridement and synovectomy) and appropriate chemotherapy, according to the results of culture and sensitivity testing, are needed for treatment.

I thank Mr Y K Lee for permission to study some of his patients and Mr F Thompson for helpful comments on the manuscript.

1 Inman PM, Beck A, Brown AE, Stanford JL. Outbreak of injection abscesses due to mycobacter ium abscesses. Arch Dermatol 1969;100: 141-7.

2 Borghans JGA, Stanford JL. Mycobacterium chelonei in abscesses after injection of diphtheriapertussus-tetanus-polio vaccine. Am Rev Respir Dis 1973;107:1-8.

Petrini B, Hellstrand P, Eriksson M. Infection with Mycobacterium chelonei following injections. Scand I Infect Dis 1980;12:237-8.

4 Foz A, Roy C, Jurado J, Arteaga E, Ruiz JM, Morgas A. Mycobacterium chelonei iatrogenic infections. J Clin Microbiol 1978;7:319-21.

5 Wallace RJ, Swenson JM, Silcox VA, Good RC, Tschen JA, Stone MS. Spectrum of disease due to rapidly growing mycobacteria. Rev Infect Dis 1983;5:657-79.

(Accepted 31 October 1985)

Department of Orthopaedic Surgery, Queen Mary Hospital, Hong Kong JAMES HON-KIT LAU, FRCS, medical officer

Correspondence to: Orthopaedic Unit, Whiston Hospital, Prescot, Merseyside L35 5DR.

\section{Minimal change nephrotic syndrome presenting after acute decompression}

Decompression sickness is a syndrome with protean manifestations, but the nephrotic syndrome has not been reported. We describe a patient who, after decompression, presented with the nephrotic syndrome, which was due to minimal change glomerulonephritis.

\section{Case report}

A 19 year old diver had to ascend rapidly from a depth of roughly $30.5 \mathrm{~m}$ because he ran out of oxygen during a normal dive 10 days before presenting to us. On surfacing he experienced substernal chest pain, headache, and dizziness and had abdominal cramps and increased bowel motions but no aches in the muscles or joints. The following day he had puffy eyelids and swollen ankles. These symptoms did not improve, and he received recompression treatment (six hours) at a centre for decompression sickness 72 hours after the incident. He defaulted after the first session, believing that he was cured. Six days later he was admitted to our unit with shortness of breath and generalised anasarca. No symptoms of recent upper respiratory tract infection were present, and he had previously been in good health with no history of symptoms suggesting renal disease.

Physical examination showed generalised oedema, more noticeable in the legs than arms, and also ascites and bilateral pleural effusion. Blood pressure was $120 / 80 \mathrm{~mm} \mathrm{Hg}$. Investigations showed a normal haemoglobin concentration and platelet count and white cell count with normal differential. Urine analysis showed proteinuria but no glycosuria, and microscopy showed normal sediments. Urine protein excretion $(24 \mathrm{~h})$ was $18.5 \mathrm{~g}$ and endogenous creatinine clearance $125 \mathrm{ml} / \mathrm{min}$. Serum concentrations were: urea $7.8 \mathrm{mmol} / \mathrm{l}(46.8 \mathrm{mg} /$ $100 \mathrm{ml})$, creatinine $89 \mu \mathrm{mol} / \mathrm{l}(1 \mathrm{mg} / 100 \mathrm{ml})$, sodium $141 \mathrm{mmol}(\mathrm{mEq}) / 1$ potassium $3.5 \mathrm{mmol}(\mathrm{mEq}) / 1$, chloride $111 \mathrm{mmol}(\mathrm{mEq}) / \mathrm{l}$, bicarbonate 24 $\mathrm{mmol}(\mathrm{mEq}) / \mathrm{l}$, urate $0.36 \mathrm{mmol} / \mathrm{l}(6.05 \mathrm{mg} / 100 \mathrm{ml})$, calcium $1.44 \mathrm{mmol} / \mathrm{l}(5.8$ $\mathrm{mg} / 100 \mathrm{ml})$, phosphate $1.47 \mathrm{mmol} / 1(4.6 \mathrm{mg} / 100 \mathrm{ml})$, albumin $11 \mathrm{~g} / \mathrm{l}$, globulin 21 $\mathrm{g} / \mathrm{l}$, cholesterol $12.5 \mathrm{mmol} / \mathrm{l}(483.4 \mathrm{mg} / 100 \mathrm{ml})$, and triglyceride $2.6 \mathrm{mmol} /$ $(230 \mathrm{mg} / 100 \mathrm{ml})$. Immunological variables were: $\operatorname{IgG} 3.99 \mathrm{~g} / \mathrm{l}, \mathrm{IgA} 2 \cdot 16 \mathrm{~g} / \mathrm{l}, \mathrm{IgM}$ $3 \cdot 26 \mathrm{~g} / \mathrm{l}$, and $\mathrm{IgE} 2998 \mathrm{IU} / \mathrm{ml}$. A hepatitis B surface antigen test was negative.

A chest $x$ ray film confirmed bilateral pleural effusion, and a film of the abdomen showed normal renal shadows. Percutaneous renal biopsy was performed and the tissue examined under light microscopy, immunofluorescence, and electron microscopy. Light microscopy showed unremarkable glomerul

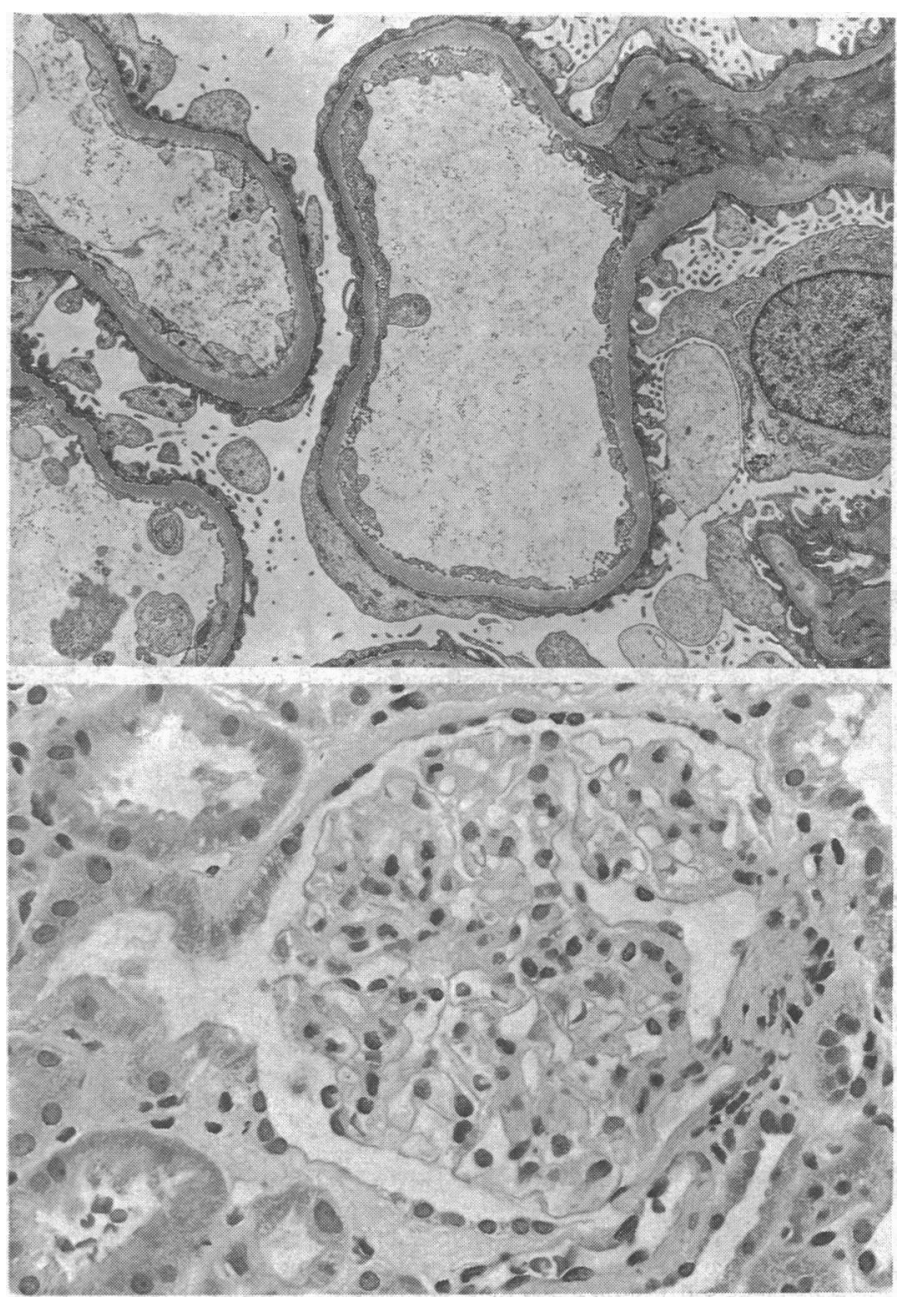

Micrographs of glomeruli (above; original magnification $\times 250$ ), and diffuse foot process fusion of podocytes (below; original magnification $\times 3600$ ) with no electron dense deposits. 
(figure). Capillary loops were not thickened and no trichrome positive deposits were seen. The tubules, interstitium, and blood vessels were all normal. Immunofluorescence studies were negative for all immunoglobulins, fibrin, and $\beta-1 C$. Electron microscopy showed diffuse foot process fusion of the podocytes (see figure) with no electron dense deposits. The basement membrane was normal.

He received corticosteroids, and his oedema decreased dramatically in two weeks. He again defaulted follow up.

\section{Comment}

Our patient clearly had mild decompression sickness with substernal pain, dizziness, headache-usual symptoms of the decompression syndrome - and minimal change glomerulonephritis. Any association between the two conditions is difficult to ascertain. Rapid ascent to the surface after diving causes decompression sickness because inert gases, mainly nitrogen, which are dissolved in the blood and tissues, come out of solution and form bubbles that produce embolism. The protean manifestations of decompression sickness cannot be completely explained by the physical effects of the bubbles. Interface of blood and bubbles causes protein denaturation, increases platelet adhesiveness, produces red cell sludging in the microcirculation, and promotes the formation of lipid emboli. ${ }^{1}$ Localised oedema occurs in $9 \%$ of patients with acute decompression sickess, ${ }^{2}$ although we know of no reports of generalised oedema. Minimal change glomerulonephritis might be the result of rapid change in environmental pressure, especially if the glomerular basement membrane is regarded as a thixotropic gel. ${ }^{3}$ The occurrence of the nephrotic syndrome with decompression sickness might have been coincidental. The change in environmental pressure on rapid ascent after diving, therefore, probably accelerates and aggravates oedema, perhaps the reverse of what occurs in up to the neck immersion in water. ${ }^{+}$

1 Elliot DH, Hallenbeck JM, Bove AA. Acute decompression sickness. Lancet 1974;ii:1193-9. 2 How J, West D, Edmonds C. Decompression sickness in diving. Singapore Med 7 1976;17:92-6. 3 Simpson LO. Basement membranes and biological thixotropy: a new hypothesis. Patholog 1980;12:377-89.

4 Epstein $M$. Renal effects of head-out water immersion in man: implications for an understanding of volume homeostasis. Physiol Rev 1978;58:529-81.

(Accepted 11 November 1985

Departments of Medicine and Pathology, University of Hong Kong, Queen Mary Hospital, Hong Kong

$P$ D YIN, honorary research associate

$\mathrm{K}$ W CHAN, MB, MRCPATH, lecturer in pathology

$M$ K CHAN, MD, FRCPED, reader in medicine

Correspondence to: Dr M K Chan.

\section{Heart failure and breast enlargement suggesting cancer}

Unilateral or asymmetric pleural effusions are a well recognised clinical finding in moderate cardiac failure. ${ }^{1}$ We should like to add breast enlargement mimicking malignancy to the unilateral manifestations of congestive cardiac failure.

\section{Case reports}

CASE 1

An 81 year old woman presented with a three week history of general malaise with swelling of the right arm and right breast and increasing abdominal girth. Nine months previously she had been admitted with episodic dyspnoea. Clinically she had had right basal consolidation and mild congestive cardiac failure. Chest radiography had suggested pulmonary infarction. She was not given anticoagulants but responded to antibiotics and diuretics. At outpatient follow up at eight months she was well.

At her second presentation she was short of breath at rest and had massive pitting oedema to the sacrum, over the right flank, and over the whole of the righ arm. The right breast was enlarged and also showed pitting oedema (figure). There was tender hepatomegaly and bilateral pleural effusions. Clinical findings suggested congestive cardiac failure and an underlying malignancy of the right breast or chest wall. Chest radiography showed cardiomegaly and bilateral pleural effusions, the right greater than the left. Pleural aspiration yielded yellow transudate (protein concentration $21 \mathrm{~g} / 1$ ) containing scanty inflammatory cells and no malignant cells. Mammography and xerography showed no evidence of malignancy. Phlebography of the right arm showed patency of all veins including the superior vena cava.

Treatment with fluid restriction, frusemide, and ethacrynic acid produced satisfactory diuresis with resolution of all symptoms and $6 \mathrm{~kg}$ weight loss.

CASE 2

A 77 year old woman was admitted with a recurrence of heart failure. She complained of exertional dyspnoea, ankle swelling, and heaviness of the right breast. She had a 13 year history of hypertension. In the preceding six months she had been treated as an inpatient for congestive cardiac failure. She was taking captopril $25 \mathrm{mg}$ thrice daily.

On examination she had the signs of severe right ventricular failure. The right breast was enlarged, the nipple was inverted, and the skin around the nipple had a peau d'orange appearance with pitting oedema. No definite mass was felt.

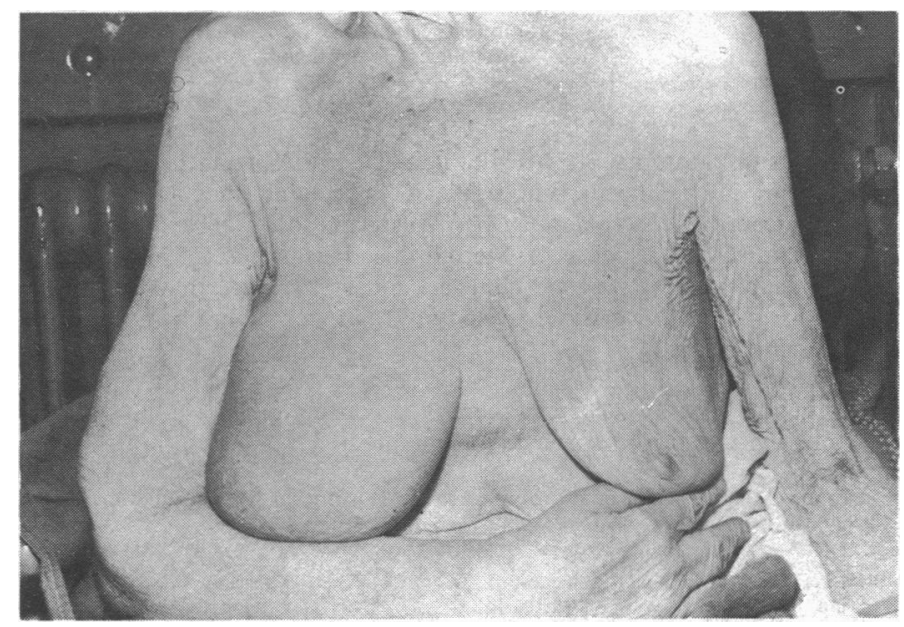

Enlarged right breast due to cardiac failure.

Carcinoma of the breast and congestive cardiac failure were provisionally diagnosed. Chest radiography showed cardiomegaly with bilateral pleural effusions.

Treatment with frusemide and captopril improved all her symptoms, with $7 \mathrm{~kg}$ weight loss. At six months' follow up the breast remained normal.

\section{Comment}

We suggest that unilateral breast enlargement mimicking breast cancer is a feature of congestive cardiac failure and should be considered in the differential diagnosis of breast disease in patients with a history of cardiac disease. Both patients presented with breast enlargement as a major symptom and had a history of uncontrolled congestive cardiac failure. Both had other clinical features to support a preliminary diagnosis of breast malignancy-namely, unilateral swelling of the arm, nipple retraction, or peau d'orange. Both responded to standard management of cardiac failure with complete resolution of the breast changes.

Unilateral breast enlargement might be due to the patient's tendency to lie on one side, which could lead to dependent oedema. The atrophic breast of elderly women may be more susceptible than younger tissue. Hoeffen and Lanyi described bilateral breast oedema in severe anasarca. ${ }^{2}$ Muller and Koehler reported a case of the nephrotic syndrome with unilateral breast enlargement associated with generalised oedema of the arms and legs and a case in which a mass in an enlarged breast resolved with treatment of cardiac failure. $^{3}$

We thank Dr G Beynon for encouraging us to report these cases.

1 Braunwald E, ed. Heart disease. Philadelphia: WB Saunders, 1984:497.

2 Hoeffken W, Lanyi M. Mammography. Stuttgart: Thieme, 1977:300-5.

3 Muller JWT, Koehler PR. Cardiac failure simulating inflammatory cancer of the breast. Fortschr Geb Rontgenstr Nuklearmed Erganzungsband 1984;140:441-4.

(Accepted 15 November 1985)

Department of Geriatric Medicine, Middlesex Hospital, London W1N 8AA G MCELLIGOTT, MB, MRCP, registrar M G HARRINGTON, MA, MRCP, senior registrar

Correspondence to: Dr McElligott. 